\title{
APPLICATION OF ARTIFICIAL NEURAL NETWORKS IN MODELLING THE CONTACT AREA OF GRAIN SEEDS
}

\author{
Jarosław Frączek, Sławomir Francik, Zbigniew Ślipek, Adrian Knapczyk \\ Department of Mechanical Engineering and Agrophysics, University of Agriculture in Krakow \\ *Corresponding author: e-mail: Slawomir.Francik@ur.krakow.pl
}

\begin{tabular}{|c|c|}
\hline ARTICLE INFO & ABSTRACT \\
\hline $\begin{array}{l}\text { Article history: } \\
\text { Received: August } 2016 \\
\text { Received in the revised form: } \\
\text { September } 2016 \\
\text { Accepted: September } 2016 \\
\end{array}$ & $\begin{array}{l}\text { The objective of the research was to create a model which defines the } \\
\text { relation between a fundamental contact area of a seed and the pressure } \\
\text { force, water content in a seed and its geometrical dimensions with } \\
\text { application of artificial neural networks (SSN). Computer program } \\
\text { Statistica Neural Networks v. 6.0. was used for formation of a neural }\end{array}$ \\
\hline $\begin{array}{l}\text { Key words: } \\
\text { contact area, } \\
\text { seed material, } \\
\text { artificial neural networks }\end{array}$ & $\begin{array}{l}\text { model. Tests were carried out on Roma wheat seed and Dańkowskie } \\
\text { Złote rye with six various water contents: } 0.110 .150 .190 .230 .28 \\
0.33 \text { (kg.kg-1 dry mass). Caryopses were loaded with eight values of } \\
\text { compression force - from } 41 \mathrm{~N} \text { to } 230 \mathrm{~N} \text {. Multiplicity of iterations } \\
\text { was } 5 \text {. Seed material was moistened to obtain a specific water content. } \\
\text { Each seed was loaded with compression force with respectively } \\
\text { growing values: } 41 \mathrm{~N}, 68 \mathrm{~N}, 95 \mathrm{~N}, 122 \mathrm{~N}, 149 \mathrm{~N}, 176 \mathrm{~N} \text {, } 203 \mathrm{~N} \text { and } 230 \mathrm{~N} \text {. } \\
\text { A four-layer network of Perceptron type with } 10 \text { neurons in the first } \\
\text { and } 8 \text { neurons in the second hidden layer was selected as a model } \\
\text { which the best defines the contact area of grain seeds loaded with } \\
\text { axial force at various moisture levels. This network has } 4 \text { inputs } \\
\text { (water content, pressure force, thickness and length of caryopses) and } \\
\text { one output (elementary contact area of rye and wheat seeds). Compar- } \\
\text { ison of the neural model with empirical formulas obtained from non- } \\
\text { linear estimation proved a considerable higher precision of the first } \\
\text { one. }\end{array}$ \\
\hline
\end{tabular}

\section{Introduction}

Plant granular material consists of the seed beds of crops which constitute a separate group which we include to the wide class of materials generally called loose materials. On account of two characteristic influences: existence of static friction and non-elastic collisions and on account of very low energy of thermal movements in comparison to potential energy of gravitational field, loose materials are often considered as a separate physical state (Ślipek et al., 1999). Behaviour of such type of materials is a sum of relations both known and still investigated (Mohsenin, 1970; Jouki et al., 2012; Balasubramanian et al., 2012; Zare et al., 2013). Their number is so significant that the obtained results of measurements concerning physical properties of loose materials are defined by considerable distributions of values (Francik and Frączek, 2001). 
Still, the area concerning phenomena which take place between particular elements of a bed and the structural material is almost unknown. It also concerns determination of the value of the contact area, which is indispensable in many cases. We can mention here the problem of correct determination of the value of contact strains during a test of seed compression and determination of the external friction force. The size of this area is also particularly important in case of a discussion on the pressure force of seed mass to the bottom and walls of a container. The current research show that friction occurring on the contact area of granular material with a flat surface depends mainly on the pressure force and the contact area field - thus on the stresses which occur on the contact area. Despite this, only some of the research concerning the friction phenomenon included the contact area.

The contact area may be defined in multiple ways:

- regular contact area - the total area taken by a seed

- real contact area - area of a direct contact of bodies. In case of a seed mass it is considered as a total value of all unit microcontacts with the total area which constitutes only a small fraction of the nominal contact area.

- an elementary contact area - real contact area defined for a single seed.

In majority of cases in the current research only a nominal contact area was usually considered. Only some measurements carried out randomly concerned an elementary area (Molenda et al., 1995; Frączek et al., 2000; Frączek, 2003; Frączek et al., 2003; Kiełbasa, 2005; Łukaszuk et al., 2009). It impeded the possibility of application of the obtained results in practice since a model of the plant seed structure has not been formed and any relation between an elementary area and determining factors was not defined.

The research concerning modelling of the seed structure are carried out in a relatively low scale (Horabik and Molenda, 2003; Romański, 2004; Romański et al., 2005; Chigarev, 2013). Thus, their extension seems necessary. It should allow better reflection of real conditions and thus increase precisions of calculations concerning various types of structures: tanks, silos, transporting devices etc. It is particularly significant presently when a wide choice of modern construction materials requires their proper selection.

\section{Objective and scope of research}

The objective of the presented research was to create a model which defines relations between an elementary contact area of a seed and the pressure force, water content in a seed and its geometrical dimensions with the use of artificial neural networks (SSN).

The following hypothesis was used as a basis for the model:

$$
\boldsymbol{P}=\mathrm{f}(N, Z, A, B, C)
$$

where:

$$
\begin{array}{ll}
P & \text { - elementary contact area of a seed, }\left(\mathrm{mm}^{2}\right) \\
N & \text { - pressure force to the tested seed, }(\mathrm{N}) \\
Z & \text { - water content in a seed, }\left(\mathrm{kg} \cdot \mathrm{kg} \cdot{ }^{-1} \mathrm{~S} . \mathrm{m}\right) \\
A & \text { - thickness of caryopses, }(\mathrm{mm}) \\
B & \text { - width of caryopses, }(\mathrm{mm}) \\
C & \text { - length of caryopses, }(\mathrm{mm})
\end{array}
$$


Application of artificial neural networks...

Tests were carried out on Roma wheat seed and Dańkowskie Złote rye. Dry seed material $\left(0.11 \mathrm{~kg} \cdot \mathrm{kg} \mathrm{s.m} .^{-1}\right)$ was moistened to the moment water content was achieved on six various levels: $0.11 ; 0.15 ; 0.19 ; 0.23 ; 0.28 ; 0.33 \mathrm{~kg} \cdot \mathrm{kg}^{-1}$ dry mass. Each seed was loaded with a compression force with respectively growing values: 41, 68, 95, 122, 149, 176, 203 and 230 N. Multiplicity of iterations was 5.

\section{Methodology}

Investigations were divided into two stages: the first one - were the contact area was measured and the second one - when approximation of the obtained results with a power function was carried out and an optimal artificial neural network was developed (Fig. 1).

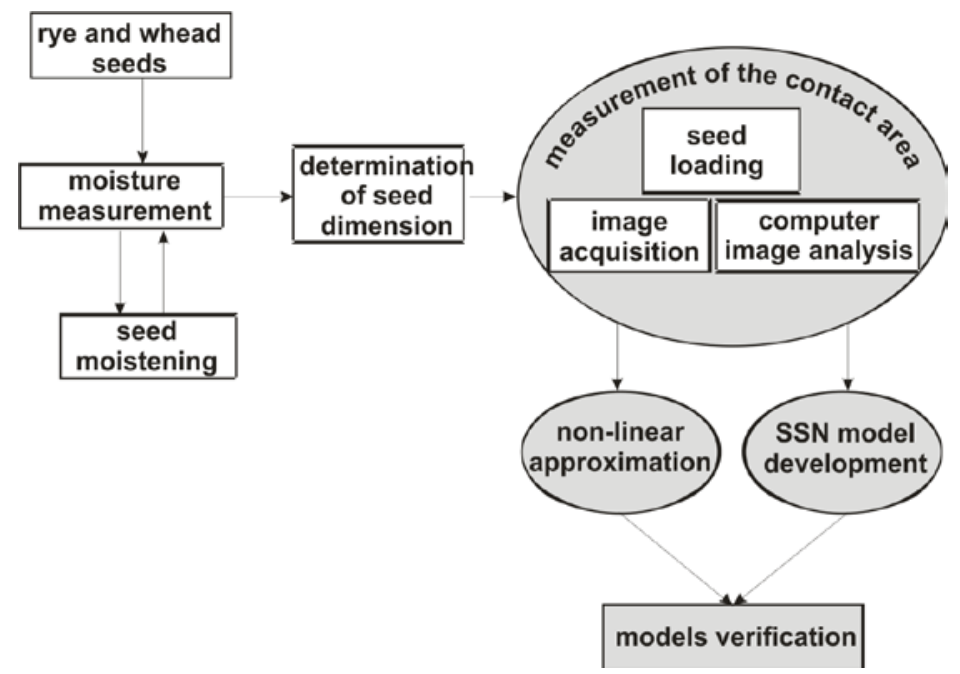

Figure 1. Schematic diagram of experiment

Seeds of the most numerous fraction obtained as a result of selection of material on laboratory screens was used for measurements. Measurement of the water content in seeds was carried out with the use of weighting machine WPE -300 S.

Tests were carried out on a research stand (Fig. 2) in the Department of Mechanical Engineering and Agrophysics of the University of Agriculture in Krakow according to the methodology presented in the paper by Frączek et al., (2000). The bottom of the measuring casette (2) with dimensions $70 \mathrm{~mm} 120 \mathrm{~mm}$ consisted of a glass plate (8) with the thickness of $5 \mathrm{~mm}$ with a template on it (4). The cover of the casette (3) was moving which enabled the pressure on the granular material. Before each seed was placed in the casette, its dimensions were determined with the use of an electronic caliper. There were three seeds mechanically loaded with loads hanging on the lever arm (1) in a measuring casette (in spots indicated by a template) at one time. The image of the contact area was registered with the use of a camera placed on a tripod under the measuring cassette. 


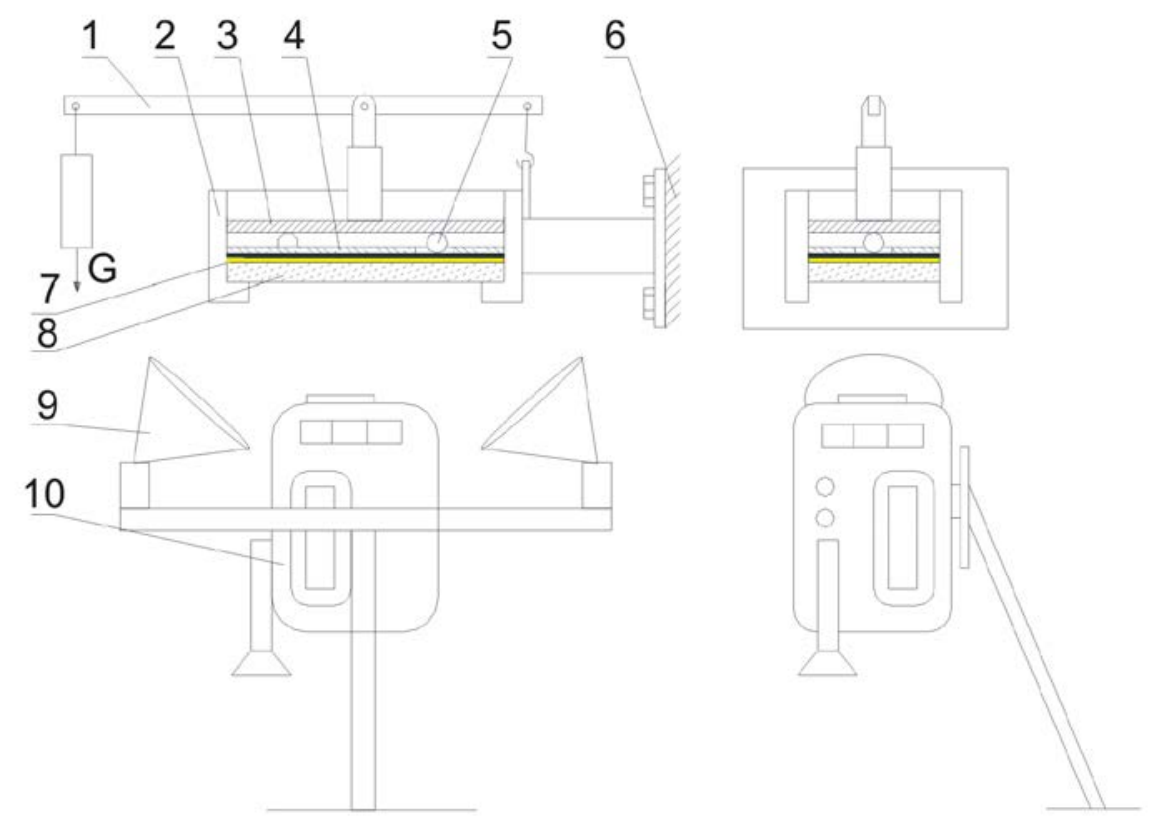

Figure 2. Schematic diagram of test stand: 1 - lever; 2 - measuring; 1 - lever; 2 - measuring cassette; 3 - cover; 4 - frame; 5 - investigated material; 6 - mounting a stand; 7 - carbon paper; 8 - glass plate; 9 - non-shadow illuminators; 10- camera

A real contact area was determined with the use of a digital image analysis (DIA). Calculations were carried out in Multi Scan program.

Caryopses were randomly placed in a frame placed in a measuring casette. In order to ensure even loading the measurements were carried out on three caryopses placed on the triangle tops. A measuring field was illuminated evenly by non-shadow illuminators. Pictures were taken with Nikon D800 camera with FX matrix with 36.3 million pixels in 7360x4912 resolution and JPEG+RAW format. When the obtained digital image was read into Multiscan program single imprints of seeds were cut out maintaining a uniform surface area of all underimages which was $121 \mathrm{~mm}^{2}$. Then the underimages were subjected to further processing and analysis which aims at such transformation which would enable carrying out a measurement of the contact area on the binary image. Thus, a filter which removes hums and binarization with an upper threshold 100 were respectively applied. Measurement of the contact surface area was the last stage on such processed image. This measurement has high precision and aims at counting points (pixels) which form a given area. The obtained result expressed in the percentages of participation of the grey surface area to the surface area of the entire analysed image was calculated into the elementary surface area expressed in square millimetres.

The obtained results served for construction of appropriate neurone network. Neurone networks allow development of a successfully operating model without a need to create 
Application of artificial neural networks...

a theory, and comparison of models using SSN with empirical formulas shows that the first ones are more precise (Francik i Frączek, 2001; Fang et al., 2000; Nasirahmadi et al., 2014.). Application of SSN additionally allows formation of models based on the results of measurements abberrated with considerable random errors (processing of noisy patterns) which in case of biological materials which are highly variable and in case of difficulties in their measurement, is one of the most important advantages (Slipek et al., 2003). Additionally artificial neural networks can generalize the acquired knowledge.

Formation of a neural model with the use of a computer program Statistica Neural Networks v. 6.0 took place in few stages:

- preparation of data for neural networks - data obtained from measurements (1440 patterns) were randomly divided into three groups: training dataset (720 pattern), validation (360 pattern) and testing (360 patterns).

- creation of models and initial training of artificial neural networks - Automatic Designer of Statistica program was used; 100 various types of neural networks were investigated: linear networks (LIN), networks with radial base function (RBF) and multi-layer perceptrons (MLP) from which 10 best models were selected; selection was made based on the minimal error value for the training dataset; various algorithms of training were applied: for MLP an algorithm of error back propagation and conjugate gradient for RBF networks, training algorithm of k-averages and k-closest neighbours and pseudoinversion, for LIN - psuedoinversion algorithm.

- training of the best neural networks in order to increase precision of operation of the model; the same algorithms as in the initial training were used;

- selection of the best model - a mean square error $E_{R M S}$ calculated for the validation dataset according to the following formula was used as a selection criterion (Dreyfus et al. 2005):

$$
E_{R M S}=\sqrt{\frac{1}{N_{w}} \cdot \sum_{k=1}^{N_{w}}\left(y_{p o m}-y_{s s n}\right)^{2}}
$$

where:

$y_{\text {pom }} \quad$ - value of the dependent variable obtained from the measurement

$y_{\text {ssn }} \quad$ - value of the dependent variable generated by artifical neural network

$N_{w} \quad$ - number of patterns in the validation dataset

Precision of the selected SSN was compared to the precision of empirical formulas obtained due to non-linear approximation (separately from rye and wheat). The highest fidelity of adjustment was obtained for the power function of the format:

$$
P=\left(\frac{A}{C}\right)^{a} \cdot\left(\frac{B}{C}\right)^{b} \cdot Z^{C} \cdot N^{d}
$$

where:

$$
\begin{array}{ll}
P & \text { - elementary contact area, }\left(\mathrm{mm}^{2}\right) \\
A & \text { - thickness of caryopses, }(\mathrm{mm}) \\
B & \text { - width of caryopses; }(\mathrm{mm})
\end{array}
$$




$$
\begin{array}{ll}
C & \text { - length of caryopses, }(\mathrm{mm}) \\
Z & \text { - water content, }\left(\mathrm{kg} \cdot \mathrm{kg}^{-1} \mathrm{~s} . \mathrm{m} .\right) \\
N & \text { - pressure force, }(\mathrm{N}) \\
a, b, c \text { - model constant, }(-)
\end{array}
$$

\section{Research results}

Among the 10 best neural models obtained as a result of the use of Automatic Designer there were 3 linear networks, 3 RBF networks and 4 networks of multilayer perceptron type (characteristics of the network was presented in table 1).

Table 1.

Characteristics of neural models

\begin{tabular}{lccccc}
\hline \multirow{2}{*}{ Model } & Network type & $\begin{array}{c}\text { Number } \\
\text { of inputs }\end{array}$ & Input variables & Number of neurons in layers \\
\cline { 3 - 6 } & LIN 1:1-1:1 & 1 & $\mathrm{X}_{2}$, & 0 & hidden 1 \\
sn01 & LIN 2:2-1:1 & 2 & $\mathrm{X}_{2}, \mathrm{X}_{1}$, & 0 & 0 \\
sn02 & LIN 3:3-1:1 & 3 & $\mathrm{X}_{2}, \mathrm{X}_{1}, \mathrm{X}_{5}$, & 0 & 0 \\
sn04 & MLP 2:2-6-5-1:1 & 2 & $\mathrm{X}_{2}, \mathrm{X}_{1}$, & 6 & 5 \\
sn05 & RBF 5:5-66-1:1 & 5 & $\mathrm{X}_{2}, \mathrm{X}_{1}, \mathrm{X}_{3}, \mathrm{X}_{4}, \mathrm{X}_{5}$ & 66 & 0 \\
sn06 & RBF 5:5-61-1:1 & 5 & $\mathrm{X}_{2}, \mathrm{X}_{1}, \mathrm{X}_{3}, \mathrm{X}_{4}, \mathrm{X}_{5}$ & 61 & 0 \\
sn07 & RBF 5:5-67-1:1 & 5 & $\mathrm{X}_{2}, \mathrm{X}_{1}, \mathrm{X}_{3}, \mathrm{X}_{4}, \mathrm{X}_{5}$ & 67 & 6 \\
sn08 & MLP 3:3-6-1:1 & 3 & $\mathrm{X}_{2}, \mathrm{X}_{1}, \mathrm{X}_{4}$ & 6 & 8 \\
sn09 & MLP 3:3-10-8-1:1 & 3 & $\mathrm{X}_{2}, \mathrm{X}_{1}, \mathrm{X}_{4}$ & 10 & 8 \\
sn10 & MLP 4:4-10-8-1:1 & 4 & $\mathrm{X}_{2}, \mathrm{X}_{1}, \mathrm{X}_{3}, \mathrm{X}_{5}$ & 10 & 0 \\
\hline
\end{tabular}

where: $\mathrm{X}_{1}$ - pressure force; $\mathrm{X}_{2}$ - content of $\mathrm{H}_{2} \mathrm{O} ; \mathrm{X}_{3}$ - thickness of $\mathrm{A} ; \mathrm{X}_{4}$ - width $\mathrm{B} ; \mathrm{X}_{5}$ - length $\mathrm{C}$

After the stage of initial training the error value $E_{R M S}$ (for data from the validation dataset) were within (fig. 3):

- from 2.63 to $3.92 \mathrm{~mm}^{2}$ for linear networks,

- from 1.89 to $1.90 \mathrm{~mm}^{2}$ for RBF network,

- from 1.94 to $2.23 \mathrm{~mm}^{2}$ for MLP network.

The lowest values were obtained by the following networks: RBF (networks with radial base functions) and MLP (multilayer perceptrons). For further training only the following networks were qualified: RBF and MLP.

As a result of the training process of the best models decrease of the error value $E_{R M S}$ for the MLP network (Figure 4) and increase of the mean square error value for the RBF network was obtained. It was found out that the lowest values $E_{R M S}$ for validation dataset were obtained by the four layer perceptron type $\operatorname{sn} 09\left(E_{R M S}=1.86 \mathrm{~mm}^{2}\right)$ and $\operatorname{sn} 10$ $\left(E_{R M S}=1.82 \mathrm{~mm}^{2}\right)$. 
Application of artificial neural networks...

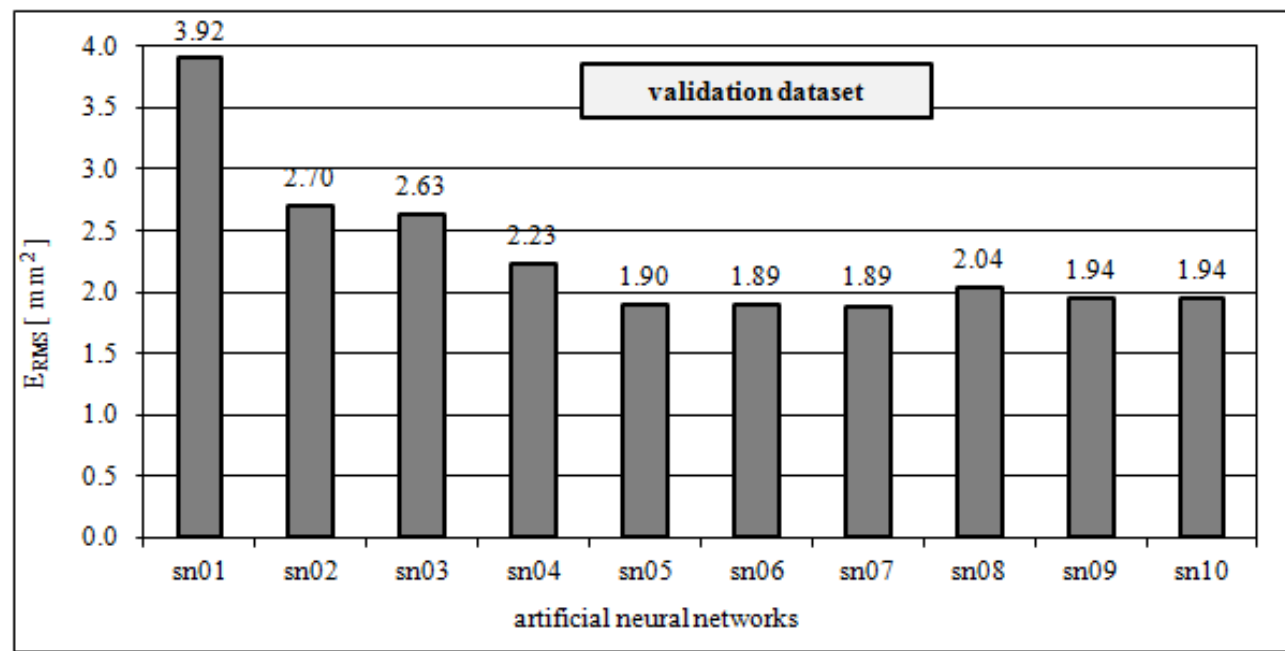

Figure 3. Error value $E_{R M S}$ for the validation data after initial training

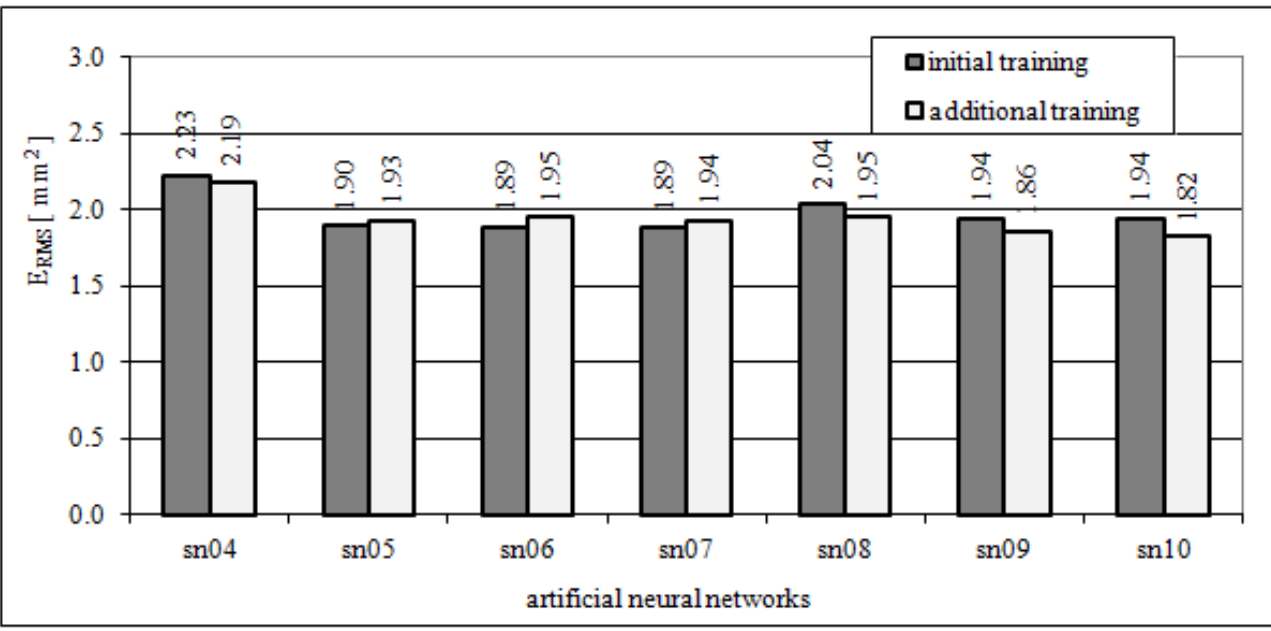

Figure 4. Error value $E_{R M S}$ for RBF and MLP network after training (validation data)

Figure 5 presents the error value $E_{R M S}$ for the best models (neural networks sn09 and sn10), for the training, validation and testing dataset. The lowest values of the mean square error were obtained for training data slightly higher for the validation and testing data.

Finally, as a model which the best suits the contact area of the wheat seed loaded with axial force at various moisture the sn10 network was selected. 
J. Frączek, S. Francik, Z. Ślipek, A. Knapczyk

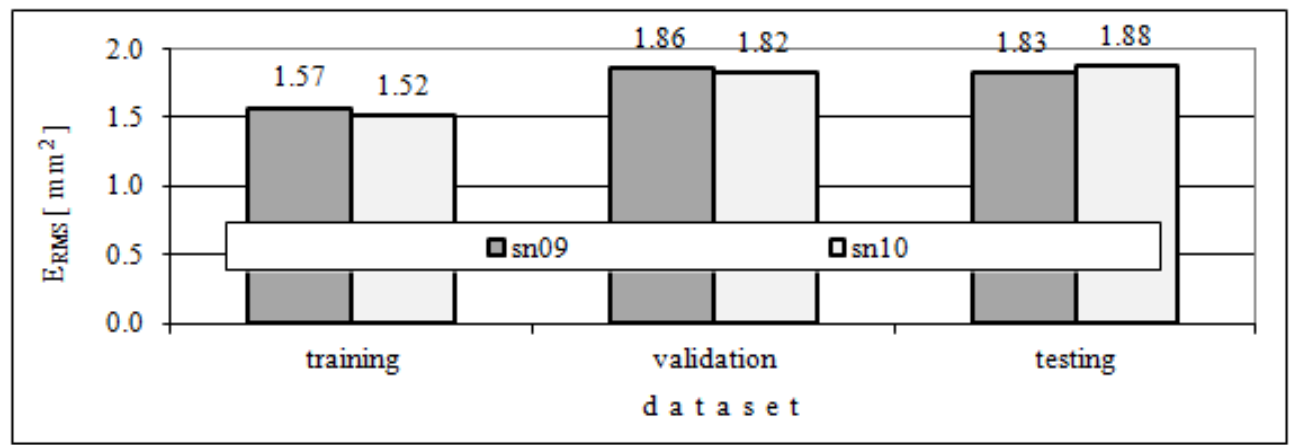

Figure 5. Error value $E_{R M S}$ for sn09 and sn10 network after training (validation data)

The structure of the neural model was presented in figure 6 . The sn10 neural network is a four-layer perceptron with 10 neurons in the first hidden layer, 8 neurons in the second hidden layer and 1 neurone in the output layer. Values of four variables are provided at the input: pressure force (X1), water content (X2), thickness (X3) and length (X5) of a caryopsis.

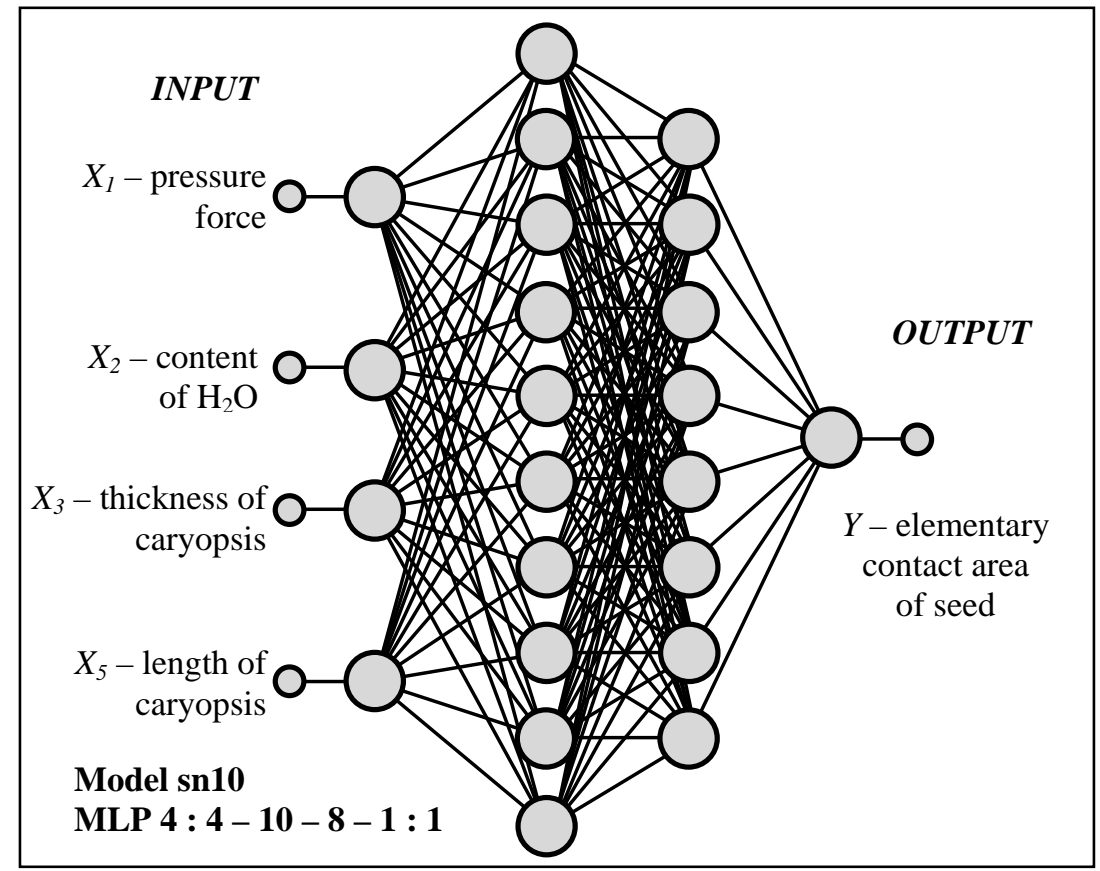

Figure 6. Sn 10 neural network structure 
Application of artificial neural networks...

According to the previously presented methodology non-linear estimation was carried out, the results of which were presented in table 2 (Statistica v. 6.0 program was used for calculations). The obtained credibility of adjustment of empirical formulas to real data is quite low - value $\mathrm{R}^{2}$ below 0.9 .

Table 2.

Approximation test results

\begin{tabular}{ccccccc}
\hline & $\mathrm{a}$ & $\mathrm{b}$ & $\mathrm{c}$ & $\mathrm{d}$ & $\mathrm{R}^{2}$ \\
\hline \multirow{2}{*}{ Wheat } & model constants & -0.935 & 0.228 & 1.783 & 0.834 & \\
& $\mathrm{SD}$ & 0.226 & 0.271 & 0.042 & 0.018 & $87.97 \%$ \\
\hline \multirow{2}{*}{ Rye } & model constants & -1.433 & 0.242 & 1.299 & 0.675 & \\
& SD & 0.169 & 0.238 & 0.48 & 0.25 & \\
\hline
\end{tabular}

Precision of neural network operation was compared to empirical formulas obtained for wheat and rye based on the test data (Fig. 7). In all cases error $E_{\text {RMs }}$ obtained lower values for the neural model sn10. For wheat, mean square error obtained for the empirical formulas was slightly higher than SSN. Quite higher difference occurred for rye (2.8 times higher error $\mathrm{E}_{\mathrm{RMS}}$ ).

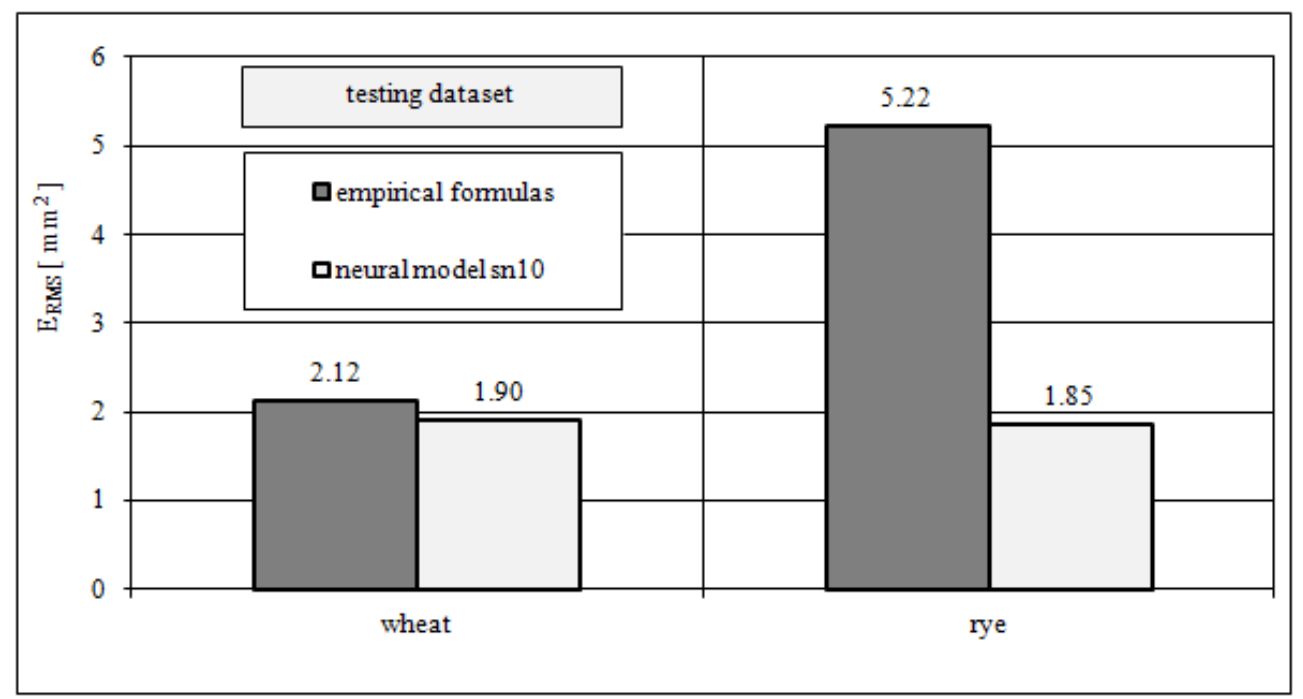

Figure 7. Comparison of neural model with empirical formulas (testing data) 


\section{Conclusion}

1. From among the tested networks, the best was a four-layer network of Perceptron type with 10 neurons in the first and 8 neurons in the second hidden layer. This network has 4 inputs (water content, pressure force, thickness and length of seed) and one output (elementary contact surface of rye and wheat seeds). The fact that the architecture of the neural model is complex the most probably results from high complexity of the described phenomenon.

2. The obtained SSN model maintained a very high ability of generalization - differences of values of $\mathrm{E}_{\mathrm{RMS}}$ for training data and validation and testing differed only by $18 \%$.

3. Comparison of the neural model with empirical formulas obtained from non-linear estimation proved higher precision of the sn10 neural network. In case of empirical formulas the mean square error value $\mathrm{E}_{\mathrm{RMS}}$ was by $12 \%$ higher for Roma wheat and by $181 \%$ higher for Dańkowskie Złote rye in comparison to the values of error for the neural network.

4. The sn10 neural network is a better device used for forecasting the value of the external friction force which occurs in the processes related to seed transport than the current empirical formulas.

\section{References}

Balasubramanian, S., Singh, K.K., Kumar, R. (2012). Physical properties of coriander seeds at different moisture content. International Agrophysics, 26, 419-422.

Chigarev, O. (2013). Model matematyczny procesu zgniatania pojedynczego ziarna w maszynie wytrzymałościowej Instron. Problemy Inżynierii Rolniczej, 1(79), 143-149.

Dreyfus, G., Martinez, J.M., Samuelides, M., Gordon, M., Badran, F., Thiria, S., Herault, L. (2005). Neural Networks, Methodology and Applications. Springer, Berlin. ISBN-13:978-3-540-22980.

Fang, Q., Hanna, M.A., Haque, E., Spillman, C.K. (2000). Neural network modeling of energy requirements for size reduction of wheat. Transactions Of The ASAE Volume: 43, Issue: 4, 947-952.

Francik, S., Frączek, J. (2001). Model development of the external friction of granular vegetable materials on the basis of artificial neural networks. International Agrophysics, 15, 231-236.

Frączek, J. (2003). Wpływ kształtu nasion na wartość powierzchni kontaktu. Inżynieria Rolnicza, 9(51), 81-88.

Frączek, J., Kaczorowski, J. i Ślipek, Z. (2000). Pomiar rzeczywistej powierzchni kontaktu trących się materiałów. Inżynieria Rolnicza, 7(18), 55-63.

Frączek, J., Kaczorowski, J., Ślipek, Z., Horabik, J., Molenda, M. (2003). Standaryzacja metod pomiaru właściwości fizyczno-mechanicznych roślinnych materiałów ziarnistych. Acta Agrophysica, 92, ISSN 1234-4525.

Horabik, J., Molenda M. (2003). Makro- i mikroskopowe modele materiałów sypkich. Acta Agrophysica, 93, 17-31.

Jouki, M., Emam-Djomeh, Z., Khazaei, N. (2012). Physical Properties of Whole Rye Seed (Secale cereal). International Journal of Food Engineering. Volume 8, Issue 4, e-ISSN 1556-3758.

Kiełbasa, P. (2005). Ocena wybranych cech fizycznych bulw ziemniaków. Inżynieria Rolnicza, 6(66), 305-313.

Łukaszuk, J., Molenda, M., Horabik, J. i Wiącek, J. (2009). Metoda wyznaczania współczynnika tarcia pomiędzy dwoma metalowymi i organicznymi obiektami. Acta Agrophysica, Vol. 13, 2, 407-418. 
Application of artificial neural networks...

Mohsenin, N.N. (1970). Physical properties of plant and animal materials. Gordon and Breach Science Publ. 1970, New York.

Molenda, M., Horabik, J., Grochowicz, M., Szot, B. (1995). Grains of wheat friction (In Polish). Acta Agrophysica, 4, ISSN 1234-4125.

Nasirahmadi, A., Abbaspour-Fard, M.H., Emadi, B., Khazaei, N.B. (2014). Modelling and analysis of compressive strength properties of parboiled paddy and milled rice. International Agrophysics, 28, 73-83.

Romański, L. (2004). Analiza i modelowanie procesu zgniatania ziarna pszenicy. Zeszyty Naukowe AR Wrocław. Rozprawy. Nr 220. ISSN 0867-7964.

Romański, L., Stopa, R., Niemiec, A. (2005). Rozkład nacisków powierzchniowych dla ziarna zgniatanego pomiędzy płaskimi płytami. Inżynieria Rolnicza, 11(71), 413-421.

Ślipek, Z., Francik, S., Frączek, J. (2003). Methodic aspects of creating ANN models in agrophysical research. Acta Agrophysica, 2(1), 231-241.

Ślipek, Z., Kaczorowski, J., Fraczek J. (1999). Theoretical and experimental analysis of vegetable materials friction. PTIR. Kraków. ISBN 83-907553-9-4.

Zare, D., Bakhshipour, A., Chen, G. (2013). Physical properties of cumin and caraway seeds. International Agrophysics, 27, 491-494.

\section{WYKORZYSTANIE SZTUCZNYCH SIECI NEURONOWYCH W MODELOWANIU POWIERZCHNI KONTAKTU ZIARNA ZBÓŻ}

Streszczenie. Celem badań było utworzenie modelu określającego zależności między elementarną powierzchnią kontaktu ziarna, a siła nacisku, zawartością wody w ziarnie oraz jego wymiarami geometrycznymi, przy wykorzystaniu sztucznych sieci neuronowych (SSN). Do tworzenie modelu neuronowego wykorzystano program komputerowy Statistica Sieci Neuronowe v. 6.0. Badania przeprowadzono na ziarnie pszenicy Roma oraz żyta Dańkowskie Złote, przy sześciu różnych zawartościach

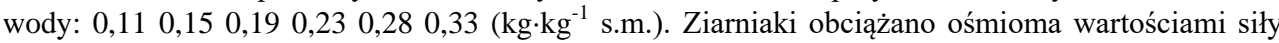
ściskającej - od $41 \mathrm{~N}$ do $230 \mathrm{~N}$. Krotność powtórzeń wynosiła 5 . Materiał ziarnisty nawilżano aby uzyskać określoną zawartość wody. Każde ziarno obciążano siłą ściskającą o kolejno rosnących wartościach: $41 \mathrm{~N}, 68 \mathrm{~N}, 95 \mathrm{~N}, 122 \mathrm{~N}, 149 \mathrm{~N}, 176 \mathrm{~N}, 203 \mathrm{~N}$ i $230 \mathrm{~N}$. Jako model najlepiej określający powierzchnię styku ziarna zbóż obciążanego siłą osiową, przy różnej wilgotności wybrano czterowarstwową sieć typu Perceptron o 10 neuronach w pierwszej i 8 neuronach w drugiej warstwie ukrytej. Sieć ta posiada 4 wejścia (zawartość wody, siła nacisku, grubość i długość ziarniaka), i jedno wyjście (elementarna powierzchnia kontaktu ziarna żyta i pszenicy). Porównanie modelu neuronowego $\mathrm{z}$ formułami empirycznymi uzyskanymi z estymacji nieliniowej wykazało zdecydowanie większą dokładność pierwszego z nich.

Słowa kluczowe: powierzchnia kontaktu, materiały ziarniste, sztuczne sieci neuronowe 